\title{
Paul's Reduction of the Dual Commandment: the significance of worldliness to messianic life
}

\author{
Gideon Baker
}

\begin{abstract}
Jesus' dual commandment to love God and neighbour, in that order, was clearly central to the teachings of the earliest communities of believers. Paul's reduction of this twin commandment (Galatians 5.13; Romans 13.9) to love of neighbour was therefore very significant, as Spinoza and Taubes both noticed. How, then, to account for Paul's audacity? Building on related readings of Paul from Heidegger and Agamben, particularly their respective interpretations of Paul's hos me ('as not') of 1 Corinthians 7.29-32, this article seeks a context for Paul's reduction. It finds it in Paul's messianic conception of worldliness as something to appropriate or use, but never as something to transcend in otherworldliness. Whether appropriation (Heidegger) or use (Agamben) is a better rendering of this insight into the messianic vocation is also discussed. While appropriation continues to assume a subject that seizes worldliness, use has the advantage of conceiving messianic subjectivity as entirely in-the-world.
\end{abstract}

The New Testament has Jesus reduce the many commandments of the law to two. The 'first and greatest' of these, the so-called Great Commandment, reads:

Hear, O Israel: The LORD our God is one LORD:

And thou shalt love the LORD thy God with all thine heart, and with all thy soul, and with all thy might (Deuteronomy 6.4-5).

To this principal commandment to love God, Jesus adds the command to love one's neighbour as oneself of Leviticus 19.17-18:

You must not hate your brother in your heart. You must surely reprove your fellow citizen so that you do not incur sin on account of him. You must not take vengeance or 
bear a grudge against the children of your people, but you must love your neighbour as yourself. I am the Lord.

Jesus combines these commandments to love God and neighbour three times in the Gospels (Matthew 22.35-40; Mark 12.28-34; Luke 10.27). This new dual commandment must therefore have been central to the teaching of the early communities of believers:

One of them, an expert in the law, tested him with this question: 'Teacher, which is the greatest commandment in the Law?'

Jesus replied: "'Love the Lord your God with all your heart and with all your soul and with all your mind". This is the first and greatest commandment. And the second is like it: "Love your neighbour as yourself". All the Law and the Prophets hang on these two commandments."' (Matthew 22.35-40)

One of the teachers of the law came and heard them debating. Noticing that Jesus had given them a good answer, he asked him, "Of all the commandments, which is the most important?"

'The most important one,' answered Jesus, 'is this: “Hear, O Israel: The Lord our God, the Lord is one. Love the Lord your God with all your heart and with all your soul and with all your mind and with all your strength.” The second is this: "Love your neighbour as yourself." There is no commandment greater than these.' (Mark 12.28-34)

Just then a lawyer stood up to test Jesus. "Teacher," he said, "what must I do to inherit eternal life?" He said to him, "What is written in the law? What do you read there?" He answered, "You shall love the Lord your God with all your heart, and with all your soul, and with all your strength, and with all your mind; and your neighbour as yourself." And he said to him, "You have given the right answer; do this, and you will live.” (Luke 10.25-8)

Although the apostle Paul's letters were written before the Gospels, it is highly unlikely that Paul would have been unaware of a teaching that ended up being so clearly expressed in them. Indeed, the dual commandment is likely 'one of the deepest recollections of the congregations'.

\footnotetext{
1 Taubes, The Political Theology of Paul, 55.
} 
This is why it is so remarkable that, for Paul, the dual commandment of Jesus, with its clearly hierarchal arrangement (in Matthew and Mark at least), must be reduced not only to one commandment alone, but to the lesser of the two. For in Galatians 5.13 we read: 'For the entire law is fulfilled in keeping this one command: "Love your neighbour as yourself". Romans 13.9 restates this reduction: 'whatever other commands there may be, [they] are summed up in this one command: "Love your neighbour as yourself".

\section{The Pauline reduction in Taubes}

Jacob Taubes, ${ }^{2}$ who apparently felt his identification of the significance of the Pauline reduction, 'this extreme reduction', to be his most enduring contribution to scholarship on Paul, believed this to be 'an absolutely revolutionary act'. ${ }^{3}$ Saying that love is simply love of neighbour might sound sentimental,

but it really isn't at all. This is a highly polemical text, polemical against Jesus. Because from the gospels we know the dual commandment [...]. Paul doesn't issue a dual commandment, but rather makes them equivocal [...] it is the love not of the Lord, but of the neighbour that is the focus here. No dual commandment, but rather one commandment [...]. [The dual commandment] belongs to the primordial core of Jesus's Christian tradition. And that Paul couldn't have missed. This is why this is a polemical formulation. This and only this is valid. ${ }^{4}$

Although Taubes identifies the significance of the Pauline reduction of the dual commandment he struggles to explain it: it is a 'problem'. ${ }^{5}$ After all, in his account a political Paul wants to replace faith (pistis, a term taken from the Imperial cult ${ }^{6}$ ) in Caesar with faith in Christ, and so there is no obvious reason why one of Christ's central teachings should be so obviously rejected. Moreover, identifying a strong Gnostic tendency in Paul, Taubes is committed to the view that Paul believes in a thoroughly transmundane God who, though he sends his son to save it, is not

\footnotetext{
2 The importance more generally of Taubes' work on Paul is discussed at length in Løland, Pauline Ugliness: Jacob Taubes and the Turn to Paul.

3 Taubes, The Political Theology of Paul, 55, 130-1. The significance of Paul's reduction still goes largely unnoticed. For example, Jesus According to Paul draws no attention whatever to the radical difference between Romans 13.9/Galatians 5.13 and Jesus' teaching.

4 Taubes, The Political Theology of Paul, 53.

${ }^{5}$ Ibid., 59.

${ }^{6}$ For more on how Paul borrows key terms from the Caesar cult, see Horsley, Paul and Empire. In particular, Horsley has shown just how political Paul's conception of pistis is, reflecting that Roman religion knew nothing of the modern divide between public and private expression of faith.
} 
of the world. ${ }^{7}$ In which case: why would love of neighbour be the same thing as the love of God? The neighbour is here, but God is elsewhere. They are not the same:

Romans 8: separated from the love of God through Christ. God's love, which Paul presumes, is very, very, far away. By powers of earthly and heavenly provenance, or archontic provenance, this love of God, of the father of Jesus Christ, is interrupted. The ray does not get through. ${ }^{8}$

The latent Gnosticism of Taubes' Paul means that his view of the world can only really be negative. This is shown by his exclusive interest in redemption. The world is good only for saving. For the same reason, creation holds no importance for Paul: 'its's just not there'. 'This means that the thread linking creation and redemption in the Pauline schema is 'A very, very thin one. And it can snap. ${ }^{10}$

Taubes is implying that Paul's reduction of the dual commandment is possible because Paul has no particular love for God, the father of Jesus and the Creator of the world. Even if Paul is not Marcion (the early Christian Gnostic who really did describe the creator-god of the Old Testament as not being the father of Jesus), nonetheless he is on the way to Marcion, who after all claimed to be faithful to Paul's letters. 'Were it not for the fact that the face-I am thinking here of 2 Corinthians - the face (prosopon) of Christ is present', what use the Father? ${ }^{11}$ 'All the father-of-Jesus-Christ passages [...] are of an ambivalent nature. Sometimes one gets the sense of an addendum. That Christ is enough, and then another addendum gets tacked on. ${ }^{12}$

Taubes' Paul is able to strike out Jesus' command to love God, settling solely for love of neighbour, because, at bottom, he is ambivalent about God the father of Jesus. Taubes recognises that there is plenty of evidence to the contrary, including in the Letter to the Romans itself (9-11). But citations are not everything, and one must consider 'the foundation in experience' before theological abstraction. ${ }^{13}$ This reference to Paul's letters being grounded in

\footnotetext{
7 Taubes, The Political Theology of Paul, 57, 60. For more on the place of Gnosticism in Taubes' thought, see Taubes, Occidental Eschatology and Styfhals, "Evil in History" and No Spiritual Investment in the World.

8 Taubes, The Political Theology of Paul, 57-8.

${ }^{9}$ Ibid., 60.

${ }^{10}$ Ibid.

${ }^{11}$ For a critique of Taubes' identification of Paul and Marcion, see Poorthuis, "The A-Cosmic Doctrine of Marcion and Paul's Apocalypticism". Weigel ("In Paul's Mask") argues that Taubes also reads Walter Benjamin as a modern Gnostic Marcionite.

12 Taubes, The Political Theology of Paul, 58.

13 Ibid., 61.
} 
lived experience is no doubt inspired by Heidegger who, as we shall see, drew very different conclusions from it.

Taubes' startling thesis that Paul is ambivalent towards God the Father, expressed at the very end of his life in the seminars (from 1987) that became The Political Theology of Paul, was really only an intensification of his long-held view that Paul's expectation of an imminent parousia led Paul, like the Gnostics, to find little of value in worldliness. Years earlier, in a 1954 book review, Taubes had discussed the same passage in 1 Corinthians (7.29-32) that we will see taken up very

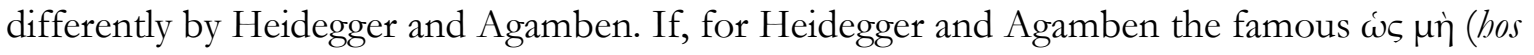
me, which Taubes here renders 'as though') of this passage suggests the worldliness of Paul's thought, for Taubes it points in the opposite direction:

[Paul] considers the old eon gone: time is short, 'it remaineth that those who have wives be as though they had none, and they that weep as though they wept not, and they that rejoice as though they rejoiced not, and they that buy as though they possessed not.' You can speak and write this way if you are convinced that 'the fashion of this world passeth away. ${ }^{14}$

Taubes is not the only one to think that there is in Paul, if not ambivalence towards God the Father, then certainly towards his created order. Paul might not be guilty of Gnostic worldhatred, but he does have a pejorative sense of world (kosmos), as Rudolf Bultmann argued:

Kosmos [world] constitutes the implicit or explicit antithesis to the sphere of God or 'The Lord', whether 'kosmos' denotes the totality of human possibilities and conditions of life (1 Cor. 3.22, 7.31), or whether it implies persons in their attitudes and judgements (1 Cor. 1.20, 27) or in their sinfulness and enmity towards God (Rom. 3.6; 19; 11.15; 2 Cor. 5.19). But this is especially true where Paul says 'this world'. ${ }^{15}$

Günther Bornkamm, too, finds Paul's kosmos to be 'the realm of Satan, the god of this aeon'. ${ }^{16}$ The 'powers of this world', if not the created order as such, are demonic. ${ }^{17}$

\footnotetext{
14 Taubes, "Against the Stream, by Karl Barth".

15 Bultmann, Theology of the New Testament, 255-6.

${ }^{16}$ Bornkamm, Paul, 129.

17 Poorthuis, "The A-Cosmic Doctrine of Marcion and Paul's Apocalypticism".
} 


\section{The Pauline reduction in Spinoza}

It is in fact questionable whether Taubes was the first to note the significance of Paul's reduction. Spinoza already identified its import in his Theological-Political Treatise:

Since obedience to God consists solely in love of our neighbour (for he who loves his neighbour, with the intention of obeying God, has fulfilled the Law, as Paul observes in his Epistle to the Romans, 13.8), it follows that the only knowledge commended in Scripture is that which everyone needs to obey God according to this command... ${ }^{18}$

Given Spinoza's call for the elevation of (universal) reason over (particular) revelation in the interpretation of scripture, Paul's reduction must have been of particular interest to him. Love of neighbour is something that all can be brought to accept, for 'the Apostles' Epistles were composed using the natural light of reason alone.${ }^{19}$ Love of neighbour is love as rational principle, while love of God, perhaps, smacks of a love that acts only for fear of punishment: 'Truly he who gives other men what is due to them because he fears the gallows, is acting at the behest of another man and under a threat of suffering harm, and cannot be called just'. ${ }^{20}$

Indeed, in an annotation to his text, Spinoza clarifies that the command to love God is not really a command at all. This 'highest precept' of 'divine natural law' is a law only

in the sense in which philosophers apply the word law to the common rules of nature according to which all things happen. For love of God is not obedience but a virtue necessarily present in someone who rightly knows God. Obedience on the other hand, concerns the will of someone who commands, not the necessity and truth of a thing. ${ }^{21}$

Love of God, if it is to be a virtue, cannot be commanded, since then it is done only out of duty rather than from the compulsion that arises when one sees for oneself what should be done. Then, 'obedience immediately turns into love which arises from true knowledge as inevitably as light emanates from the sun'. ${ }^{22}$ The (transcendent) command to love God dissipates into (immanent) love of neighbour by the light of reason:

\footnotetext{
18 Spinoza, Theological-Political Treatise, 173.

${ }^{19}$ Ibid., 159.

${ }^{20}$ Ibid., 158.

21 Ibid., 272.

22 Ibid.
} 
By the guidance of reason therefore we can love God but not obey him, since we cannot accept divine laws as divine so long as we do not know their cause, nor by reason can we conceive of God as issuing decrees like a prince. ${ }^{23}$

Spinoza does not find Paul's reduced commandment striking in and of itself because he locates it wholly within Paul's wider critique of law, which Spinoza understands as a critique of communal law. In his discussion of Romans 3.1-2, Spinoza grants that Paul appears to give to the Jews a certain privilege in regard to the law; but he immediately dismisses this reading by pointing to other passages from Romans $(3.29 ; 2.25-6 ; 3.9 ; 4.15)$ that show that 'the law has been revealed to everyone without exception' and that only this, universal, law can lead to true virtue. ${ }^{24}$ The purpose of the law, including the dual commandment, is only that men should 'no longer live good lives because the law so commanded, but from a fixed conviction of the mind'. ${ }^{25}$

Paul's critique of law, in Spinoza's treatment of it, is effectively Paul's realization that nothing commands except reason:

he who gives other men what is due to them because he knows the true rationale of laws and understands their necessity, is acting steadfastly and at his own and not another's command, and therefore is deservedly called just. I think this is what Paul meant to point out when he said that those who lived under the law could not be justified by the law. ${ }^{26}$

Spinoza finds Paul's alternative to law to be little more than 'justice, as it is commonly defined', a justice so universal that we can summarise it simply, after Justinian, as " a constant and perpetual will to assign to each man his due". ${ }^{27}$ Following the model of Christ, Paul teaches eternal truths rather than giving commandments, since this is what it means to say that Christ 'freed them from servitude to the law ${ }^{28}$ : 'divine commandments seem to us like decrees or enactments only so long as we are ignorant of their cause. Once we know this, they immediately cease to be edicts and we accept them as eternal truths'. ${ }^{29}$ When Paul says that no one is justified by the works of

\footnotetext{
23 Ibid.

${ }^{24}$ Ibid., 52-3.

25 Ibid.

${ }^{26}$ Ibid., 58.

27 Ibid., 59.

${ }^{28}$ Ibid., 64; see also 160.

${ }^{29}$ Ibid., 272.
} 
the law but only by faith (Romans 3.28), faith here 'means nothing other than full mental assent'. ${ }^{30}$ Given that 'each man fully understands by the natural light of reason the power of God', men can 'know and deduce what they should seek and what they should avoid'. ${ }^{31}$

Paul's reduced commandment allows Spinoza to say that mystical love of God is fulfilled entirely in rational love of neighbour; for even this latter love does not need to be commanded. Reason itself clearly demands it. ${ }^{32}$ To be sure, no one knows by nature alone that they should love their neighbour, but this 'state of nature' is prior to reason and religion, 'both by nature, and in time', and nothing is forbidden in it. ${ }^{33}$ Love of neighbour, then, is no natural law, but having once been brought to reason, we leave the state of nature and can see by our own lights that it compels. It no longer needs to issue from a command of God. Spinoza emphasizes the importance of this point in an annotation: to think of love of neighbour in terms of command is to ignore Paul's clear teaching that, when we are guilty, it is not because we have been 'warned beforehand' but because God 'pities whom he will and hardens whom he will'. ${ }^{34}$ We are without excuse simply because we are wholly within God's power as he fashions us, like a potter from the same clay, this one a beautiful vessel and that one a menial pot. ${ }^{35}$ In sum, it is the capacity for reason that enables us to love our neighbour, not a command that it would be a sin to ignore.

Spinoza's reading of Paul as the most philosophical of the Apostles who appeals to reason rather than nature or revelation is clearly in keeping with the rationalism informing Spinoza's own philosophical, not to mention political-theological, project. ${ }^{36}$ The Paul that Spinoza wants is captured nicely in the reduced commandment: 'Paul teaches exactly what we want to affirm'. ${ }^{37}$ Yet the significance of Paul's reduction is not Spinoza's concoction. It falls to Taubes to show just how radical it must have been in Paul's own context—given that the attribution of rationalism to Paul seems an anachronism.

\footnotetext{
30 Ibid., 64.

31 Ibid., 67.

32 In his Ethics, Spinoza specifies how reason generates love of neighbour free from all command. The general principle is that reason leads us to want nothing for ourselves that we do not also want for others (126). For reason 'teaches us to hate no one, to disesteem no one, to mock no one, to be angry at no one, to envy no one' (68). Those guided by reason, seeing 'that all things follow from the necessity of divine nature', will 'surely find nothing worthy of hate, mockery, or disdain' in their fellow man (142). Put otherwise: once we have grasped that our neighbour is caused rather than free we have little reason to hate her when she harms us (95). Keeping in mind 'that men, like other things, act from the necessity of nature, then the wrong, or the hate usually arising from it, will occupy a very small part of the imagination, and will easily be overcome' (167).

33 Spinoza, Theological-Political Treatise, 205.

34 Ibid., 272.

35 Ibid.

36 Ibid., 162

37 Ibid., 53.
} 
Taubes' insight into the radicalism of Paul's reduced commandment can be located within the radicalism of Taubes' wider thought of Paul. Taubes' Paul, perhaps more than for any previous commentator, is a Jew: 'Christian' is a term that 'doesn't yet exist for Paul'. ${ }^{38}$ But the law that Paul puts in question goes beyond his communal context. For Taubes, Paul's law is not Jewish law alone, but the whole 'apotheosis of nomos' of the culturally Hellenistic Roman Empire which Paul lived under. ${ }^{39}$ It is just as much Stoic law, namely the law of nature or the law of right reason (logos) that guides the cosmos. It is this whole 'mishmash' of Jewish, Greek and Roman law that, in Taubes' view, Paul 'clambers out' of. Paul's message is that 'It isn't nomos but rather the one who was nailed to a cross by nomos who is the imperator! This is incredible, and compared to this all the little revolutionaries are nothing..$^{40}$

Seen in the light that Taubes throws on it, Paul's reduction of the dual commandment is the radical provocation of a revolutionary nihilist. ${ }^{41}$ Much safer to reinstate the two commands, as in Christian orthodoxy:

Now God, our master, teaches two chief precepts, love of God and love of neighbour; and in them man finds three objects for his love: God, himself, and his neighbour; and a man who loves God is not wrong in loving himself. It follows, therefore, that he will be concerned also that his neighbour should love God, since he is told to love his neighbour as himself... ${ }^{42}$

\section{The hos me as use}

What is it about Paul's understanding of the good news that enables him to make such an audacious reduction of Jesus' dual commandment? Rather than approaching Paul's reduction from the standpoint of its difference to Jesus' teachings, as Taubes does, it will be helpful to understand how such a move made sense in the context of the wider identity of Paul's thought.

\footnotetext{
38 Taubes, The Political Theology of Paul, 21.

${ }^{39}$ Ibid., 23.

40 Ibid., 24.

${ }^{41}$ In this connection, it is worth recalling that Taubes (The Political Theology of Paul, 79) saw Nietzsche as his best teacher on Paul. Although Taubes gives Paul's 'nihilistic' opposition to Rome a positive valence (in place of Nietzsche's negative one), Taubes' Paul is, in spirit, not far from Nietzsche's. The biggest difference is that Nietzsche's Paul is still the founder of Christianity where Taubes reintegrates him into Jewish messianism. 42 Augustine, City of God, XIX.14.
} 
For Paul's environment, including his reception of the primordial teachings of the earliest congregations, 'first gains its sense out of [his] understanding of the situation'. ${ }^{43}$

Helpful to grasping the wider context of Paul's reduction is the reading of the Apostle offered by Giorgio Agamben in The Time that Remains. Agamben's thesis is that Paul's conception of messianic living is of an activity conducted entirely on worldly vocations, a living which therefore finds itself indifferent to otherworldliness. If this is correct then we may be able to situate Paul's reduction of the dual commandment, which after all offers worldly love of neighbour in place of otherworldly love of God, in the milieu of his messianism.

Agamben focuses on 1 Corinthians 7.29-32, likely Paul's 'most rigorous definition of messianic life':

What I mean, brothers and sisters, is that the time is short. From now on those who have wives should live as if they do not [hos me]; those who mourn, as if they did not [hos $m e$ ]; those who are happy, as if they were not [hos me]; those who buy something, as if it were not [hos me] theirs to keep; those who use the things of the world, as if not [hos me] engrossed in them. For this world in its present form is passing away (emphases added) ${ }^{44}$

Agamben, following Heidegger, does not translate hos me with the usual 'as if not' but simply 'as not'. Heidegger's reasons for rejecting the 'as if are given as follows: ““As if' expresses an objective connection, and suggests the view that the Christian should eliminate $[\ldots]$ relations to the surrounding world'. ${ }^{4}$

In Agamben's view, hos me is Paul's fundamental formula for messianic life. ${ }^{46}$ Hos me does not point to another, redeemed, world; following Heidegger, it is in no way the 'as if'. In fact, nothing in the 'messianic tension' introduced by hos me tends towards an elsewhere:

The apostle does not say 'weeping as rejoicing' nor 'weeping as [meaning =] not weeping,' but 'weeping as not weeping' [...] the weeping is pushed towards the weeping

\footnotetext{
${ }^{43}$ Heidegger, The Phenomenology of Religious Life, 59.

44 Agamben, The Time that Remains, 23.

${ }^{45}$ Heidegger, The Phenomenology of Religious Life, 86.

46 Agamben, The Time that Remains, 23.
} 
$[\ldots]$. In this manner, it revokes the factical condition and undermines it without altering its form. ${ }^{47}$

The hos me is not otherworldliness. It is even the other world's abolition, if by this we understand not its destruction but its realization. For the hos me, inasmuch as its nullification of worldliness does seek to add anything to worldliness, is really a zone of indistinction, of 'absolute indiscernibility', between this world and the world to come. ${ }^{48}$ This is why Bielik-Robson's description of revoked worldliness as a 'withdrawing from any active participation in the world' is not quite right:

By identifying the messianic vocation with the 'revocation of every vocation', Agamben forbids it to take on any 'task' that would wish to change actively the status of the world. It is to stay forever in the 'u-topia' of freedom, the 'no place' of hos me ('as not'). ${ }^{49}$

Despite, or rather because of, their now appearing in the negated form of the 'as not', worldly vocations such as marriage, mourning, happiness and so on, actually become useable. Handed over to our worldliness, consigned to it, does not mean assuming it unquestioningly nor questioning it nihilistically. It means putting it in question.

Another way of making this point is to say that, in messianic time, we inhabit our worldly vocations. This is what Agamben means when he says that the messianic vocation hollows out worldly vocations. ${ }^{50}$ If the hos me simply tore down worldly vocations there would be nowhere to dwell. But if it did not hollow them out by negating them, they would not be habitable. ${ }^{51}$ Messianic life is lived neither in the wordless place of eschatological nihilism nor in the assigned place of Greek kosmos. It's taking place is a taking-of-place. ${ }^{52}$ This is why the alternatives of leaving 'the world standing' or 'escaping it' are not exhaustive in the hos $m e^{53}$

\footnotetext{
47 Ibid., 24.

48 Ibid., 25.

49 Bielik-Robson, “A Broken Constellation”, 107.

${ }^{50}$ Agamben, The Time that Remains, 24.

51 Agamben knows that he is straying very close to the Hegelian dialectic here: the hos me 'does not merely abolish, it preserves and brings to fulfilment' (The Time that Remains, 99). As Johnson (“As If the Time Were Now”, 272) reminds us, 'This is the gesture of Hegel's Aufhebung'.

52 The spatial implications of Agamben's messianic time of the now are explored further by Barber (2011).

${ }^{53}$ Fox, "Sacrificial Pasts and Messianic Futures", 583. Although see Cimino ("Europe and Paul of Tarsus") for an argument that Agamben's version of Paul's hos me actually collapses into the former of these alternatives.
} 
To say that worldly vocations no longer have any value in the Messiah could only be nihilism. Taubes, for his part, does find 1 Corinthians 7.29-32 to be 'the nihilistic passage of the bos me ${ }^{.54}$ Having already read Paul's letter to the Romans as a direct challenge to the political power of Rome ('my thesis is that [. . . the Epistle to the Romans is a political theology, a political declaration of war on the Caesar $\left.{ }^{55}\right)$, Taubes must see the hos me as a 'why bother?':

This means: under this time pressure, if tomorrow the whole palaver, the entire swindle were going to be over-in that case there's no point in any revolution! That's absolutely right, I would give the same advice. Demonstrate obedience to state authority, pay taxes, don't do anything bad, don't get involved in conflicts, because otherwise it'll get confused with some revolutionary movement, which, of course, is how it happened. ${ }^{56}$

For Taubes, the hos me is an 'apocalyptic-eschatological profession of faith' premised on a coming end of time that will devalue everything mortal and mundane, everything worldly. ${ }^{57}$

Agamben notes, to the contrary, that although time is short, Paul does not speak of a time to come but of a time that is now: 'from now on'. Contrary to the eschatological subject, then, the messianic subject:

$[\mathrm{K}]$ nows that in messianic time the saved world coincides with the world that is irretrievably lost, and that, to use Bonhoeffer's words, he must now really live in a world without God. This means that he must not disguise this world's being-without-God in any way. The saving God is the God who abandons him [...]. The messianic subject does not contemplate the world as if it were saved. In Benjamin's words, he contemplates salvation only to the extent that he loses himself in what cannot be saved. ${ }^{58}$

In Agamben's reading, the value of worldly vocations become absolute even as they are negated in the hos me. Paul does not offer up another world. To the contrary, the hos me reveals an irreparably abandoned world, one in which God is present only in the form of his absence. But

\footnotetext{
54 Taubes, The Political Theology of Paul, 53. See also Gold, “Jacob Taubes”, 155.

55 Ibid., 16.

56 Ibid., 54.

${ }^{57}$ Ibid., 53. For a discussion of the centrality of apocalypticism to Taubes' thought, see Lynch, Apocalyptic Political Theology.

58 Agamben, The Time that Remains, 42.
} 
this is a world that, precisely because it cannot be saved, becomes the highest value. The messianic subject, indifferent to the away-from-here, is really the only worldly subject.

Agamben draws attention to Paul's summary of the hos me, which is that: 'For the present form [skhema] of this world is passing away' (1 Corinthians 7.31). ${ }^{59}$ As the recapitulation of the hos me, the explanation of that in which the hos me finds its significance, this summation is important. Agamben translates it as: 'For passing away is the figure, the way of being of this world' ${ }^{60} \mathrm{In}$ other words, it is not that the world is passing but that passing is the way of the world. ${ }^{61}$

What this alternative translation implies is that, contra otherworldliness, the hos me actually negates the passing away of worldly vocations. But since the hos me does this not in some future time but now, the hos me is actually that by which the world is made the highest value. Living passing worldly vocations as not passing does two things at once: it affirms the fundamental contingency of each and every social condition while at the same time putting these self-same conditions to use. ${ }^{62}$ The world's passing allows a reserve of potentiality that can never be subsumed in act:

The messianic vocation $[. .$.$] is a generic potentiality [potenza] that can be used without$ ever being owned. To be messianic, to live in the Messiah, signifies the expropriation of each and every juridical-factical property (circumcised/uncircumcised; free/slave; man/woman) under the form of the as not. This expropriation does not, however, found a new identity; the 'new creature' is none other than the use and messianic vocation of the old... ${ }^{63}$

Agamben's Paul posits an ontology of use of the world in place of the worldly uselessness of eschatology. (For that matter, the eternal world of Greek metaphysics is also fairly use-lesseverything has it's appointed place and should stay in it.) Likewise, Paul's messianic time, in Agamben's view, is an operational time, which is not an addition to chronological time, but rather

\footnotetext{
59 Ibid., 23.

${ }^{60}$ Ibid., 24.

${ }^{61}$ Rather differently, Rémi Brague (The Wisdom of the World, 55) sees Paul's skhema not as an abstract representation of the world but rather as a practical idea of the world that enables one to 'have a hold on life'. He follows Heidegger (The Phenomenology of Religious Life, 85) here.

62 Agamben, The Time that Remains, 31; cf. Blanton, "Dispossessed Life", xvii and Breton, The Word and the Cross. Understood thus, Agamben's rendering of the hos me is an echo of Nietzsche's pessimism of strength.

63 Ibid., 26.
} 
the Messiah's relation to each instant of chronological time. ${ }^{64}$ This is why Paul's parousia (presence) of the Messiah should not be understood as his 'second coming'. Indeed, far from being forward-looking; messianic time works backwards. In Ephesians 1.10, Paul writes that 'all things are recapitulated in him, things in heaven and things on earth' (emphasis added).

Agamben's reading explains the Pauline reduction of the dual commandment without resorting to making Paul a Gnostic-apocalyptic. While Taubes' nihilistic Paul might capture the 'not yet' of his messianic temporality, Agamben is surely right that it cannot account for the 'now'. Finding messianic presence to be a form of presence-in-absence, Agamben's Paul is able to take love of neighbour not as something that points towards higher love of God but as complete in itself. Love of God leaves love at the level of the 'as if - I love my neighbour as if I was loving God. Love of neighbour, meanwhile fulfils the messianic vocation of the hos me-I love my neighbour as not loving him, which means that, abandoned to my neighbour, I love him only in the using of love.

Agamben concedes that Taubes' 'anarchic nihilistic' interpretation of the hos me is plausible. ${ }^{65} \mathrm{He}$ wonders, however, whether Taubes' political Paul, inasmuch as his worldly vocation and messianic vocation overlap entirely, can have any awareness of the messianic vocation as such. Agamben, for his part, does not want to make the two vocations indistinguishable, even if they can never be separated, either. The 'as not' is a zone of indiscernibility where worldly vocations and the messianic vocation become indistinguishable even while never being the same thing. Although Agamben does not say so himself, it is clear that what stops them being the same thing is understanding.

The echoes of Spinoza's ethics are clear here, where the free man is 'determined to do something because he understands'. ${ }^{66}$ Note that Spinoza writes 'determined' to do something. Freedom is not lack of determination but rather being determined in one's actions by understanding. It follows that the free man 'strives most of all to conceive things as they are in themselves'. ${ }^{67}$ Returning to love of neighbour: loving my neighbour in the form of the hos me is to love him in a completely mundane way, with the small difference that I really know that my love for him can only ever be mundane.

\footnotetext{
${ }^{64}$ Ibid., 76.

65 Ibid., 33.

${ }^{66}$ Spinoza, Ethics, 127.

${ }^{67}$ Ibid., 154.
} 


\section{The hos me as appropriation}

Influenced as Agamben is by Heidegger, it is interesting to see a similar account of the context of Paul's reduction in Heidegger's early lectures on The Phenomenology of Religious Life. ${ }^{68}$ Agamben's emphasis on Paul's taking up of worldliness is prefigured in Heidegger's account of appropriated [zugeeignet] worldliness in Paul (the difference being, as we shall see, that Agamben does not think that worldliness can be appropriated, only used). Indeed, Agamben writes that

It is through his reading of the Pauline hos me that Heidegger seems to first develop his idea [as set out in Being and Time] of appropriation of the improper as the determining trait of human existence. The Christian way of life is in fact not determined by worldly relations or by their content, but by the way, and only by the way, in which they are lived and are appropriated in their very impropriety. ${ }^{69}$

As Agamben after him, Heidegger resists any reading of life-denying nihilism into Paul: 'The significances of life remain, but a new comportment arises'.$^{70}$ And as with Agamben's notion of use, this new comportment introduces change into Christian living. This is to be contrasted with the cosmos-thinking of Greek metaphysis, where change is banished: one piously finds one's place in the totality and stays in it. Know your place.

Heidegger's Paul knows nothing of this metaphysical division between the true world and the world of appearance, between being and becoming. Christian existence is a complex of becoming and it is only from out of this complex that 'the static or dynamic character of the situation is to be determined'. ${ }^{71}$ Christian enactment [Volliug] itself decides what endures and what passes. Christian living is therefore 'compressed temporality' as opposed to both lifeless eternity and the indifferent flux of time, which are the only times known to metaphysics. ${ }^{72}$

If the dual commandment parallels the two worlds structure of Greek metaphysics (God and neighbour; above and below), Heidegger's Paul offers an image of world in which that division is overcome. To be sure, the two worlds of Greek metaphysics was neither the source of Jesus'

\footnotetext{
${ }^{68}$ For more on Agamben's borrowings from Heidegger in his reading of Paul, see Delahaye, “About Chronos and Kairos".

${ }^{69}$ Agamben, The Time that Remains, 34 .

${ }^{70}$ Heidegger, The Phenomenology of Religious Life, 83.

${ }^{71}$ Ibid., 64.

${ }^{72}$ Ibid., 85.
} 
twin commandment nor similar in content to it. But grasping Paul's own understanding of such a bifurcated structure as the dual commandment must take account of his familiarity with Greek thought, which we know of from the Stoic formulations of his letters. ${ }^{73}$ In short, Paul's capacity for conceiving of Christian temporality outside of the binary of metaphysical time (eternity-flux) would likewise have enabled his reduction of the dual commandment.

Heidegger summarises Paul's concept of world-time (aeon) as follows: 'The present time has already reached its end and a new [aeon] has begun since the death of Christ. The present world is opposed to the world of eternity'. Opposing both the metaphysical sense of the world as eternal and the eschatological focus on the world's end, Paul's world, Heidegger argues, is now. ${ }^{74}$ The first letter to the Thessalonians in particular shows that Paul calls the Thessalonians to a living rather than an eternal life. ${ }^{75}$ No fixed sense can be given to religious life; the being of the believers is only their 'having-become [Gewordensein]'. Likewise, their 'having-become is their being now' ${ }^{76}$

Heidegger's Paul conceives of God's presence as leading to a transformation of life (peripatein, living), not to its remaining the same. ${ }^{77}$ Religious life, for Paul, has to be lived. No mere flow of events, it is only insofar as the Christian has it. $^{78}$ The parousia is not something the Christian anticipates as a future event. Indeed, Christian hope is not in a time to come at all. Heidegger notes that Paul does not tell the Thessalonians when Christ will return but rather announces 'you know exactly' (1 Thessalonians 5.2). ${ }^{79}$ Paul refers the parousia back to their own lives. ${ }^{80}$ What is decisive is how they live, not the exact hour of the Messiah's return: 'Paul is not concerned at all about answering the question of the When of the Parousia. The When is determined through the How of self-comportment, which is determined through the enactment of factical life experience in each of its moments. ${ }^{81}$ It is impossible to encounter primordial Christian temporality in any objective concept of time. ${ }^{82}$

\footnotetext{
${ }^{73}$ Ibid., 55; cf. Bultmann, Theology of the New Testament, 9.

${ }^{74}$ Ibid., 49.

75 Ibid., 65.

76 Ibid., 66.

77 Ibid.

78 Ibid., 70.

${ }^{79}$ Ibid., 71-2.

80 Ibid., 73.

81 Ibid., 75.

82 Ibid., 73.
} 
For Heidegger, this distinction between a parousia that is lived and one that is passively awaited is drawn out more clearly in the second letter to the Thessalonians. Here (3.11), Paul distinguishes between those who have understood his message from those who, awaiting the parousia, no longer bother to work but sit around idly discussing when the new kingdom will come. The worldliness of these errant believers — they are busy with idle chatter after all—remains entirely unappropriated. For those that have ears to hear, however, it is clear that Paul's presentation of the parousia is harsh, signalling rather an 'enlarged tension' that overburdens the Thessalonians by referring them back to themselves. ${ }^{83}$ The tension that Agamben refers to in the context of hos me - where weeping, for example, is 'pushed towards' weeping - is here found in its earlier formulation:

I Cor. 7:29-32: [...] There remains only a little time, the Christian living incessantly in only-yet, which intensifies his distress. The compressed temporality is constitutive for Christian religiosity: an 'only yet,' there is no time for postponement. The Christian should be such that those who have a wife, should have her in such a way, that they do not have her, etc. ${ }^{84}$

Just as the Thessalonians, the Corinthians are referred back to themselves because the enactment of the Christian calling does not have the character of a once-for-all 'happening'. Rather, 'that which has the character of enactment is only co-possessed in the enactment itself, [it] cannot itself be objectified' ${ }^{85}$ Indeed, as the 'enlarged tension' suggests, not only is Heidegger's Paul saying that the parousia must be lived, he is also making it the hardest thing. It is easy to sit and chatter because one expects the Lord to become present any day. Much harder is to understand that the Messiah's presence is only in its enactment (enactment is close to Agamben's 'use' here). For those who understand this there is actually an increase in anguish from before the call, but this anguish is the only proof of the calling there is. ${ }^{86}$

For Heidegger, 2 Corinthians 12:2-10 allows us to see that the same indifference to an accomplished transcendence is characteristic also of Paul's 'self-world':

\footnotetext{
83 Ibid., 76-7.

84 Ibid., 85.

85 Ibid., 77. For a discussion of the significance of 'enactment' in Heidegger's phenomenology of religious life, see Swazo, "Heidegger's Destruktion of Theology".

86 Ibid., 79. Vedder ("Heidegger's Explication of Religious Phenomena in the Letters of Saint Paul"), who translates hos me with 'as if not', prefers to emphasise the Christian's awareness of life's fragility as the key to understanding Heidegger's reading of this passage.
} 
The extraordinary in his life plays no role for him. Only when he is weak, when he withstands the anguish of his life, can he enter into a close connection with God. This fundamental requirement of having-God is the opposite of all bad mysticism. Not mystical absorption and special exertion; rather withstanding the weakness of life is decisive. $^{87}$

In place of the above and below of Greek metaphysics, Paul distinguishes between two modes of life. This means that, differently from all otherworldliness, 'Christian facticity gains no exceptionality, absolutely no special quality at all. In all its absoluteness of reorganizing the enactment, everything remains the same in respect to the worldly facticity. ${ }^{88}$ Christians do not 'step out of the world', finding only 'a new fundamental comportment' to it. ${ }^{89}$ The world of the Christian is determined solely 'out of this original enactment. ${ }^{90}$

This is why, for Heidegger, nothing of the gnostic spiritualisation of Christian existence can be found in Paul. Very differently from Taubes, Heidegger does not find Paul's 'pneumatic' living (the life in the spirit of 1 Corinthians 2) to be anything other than 'a conviction; that is to say, a tendency of life'. ${ }^{91}$ Living in the spirit is not being spirit, it not a life directed elsewhere: 'The Mystic is, through manipulation, removed from the life-complex; in an enraptured state God and the universe are possessed. The Christian knows no such "enthusiasm", rather he says: "let us be awake and sober"'.92

The influence of this reading of Paul on theology has been enduring. Bornkamm, for instance, agrees that the believer has been released by Christ in time; the Christian does not have to wait for the eschaton. And yet this liberation does not mean freedom from worldliness, in particular from humiliation and suffering. Any such Gnostic ‘enthusiasm' is rejected by Bornkamm's Paul in the name of a 'still continuing temporality'. 'Time and history', not eternity, 'are the field in which faith exercises and verifies itself.$^{93}$ Worldly time, far from being that which believers hurry to escape, is the very condition of salvation:

\footnotetext{
87 Ibid., 70 .

88 Ibid., 83.

89 Ibid., $85,84$.

90 Ibid., 85.

${ }^{91}$ Ibid., 88.

92 Ibid., 89.

${ }^{93}$ Bornkamm, Paul, 200.
} 
Thus while all Paul's utterances go beyond the individual's human experience in time and refer to the divine 'beyond', they serve the purpose of pinning believers down within the confines of the 'here', 'this side', the 'not yet' of their temporality and historicity'. ${ }^{94}$

Heidegger's reading of Paul's 'primordial Christianity' as a new relation to worldly existence, rather than any transcending of the world as such, provides a context for the Pauline reduction. Unlike those who 'remain stuck in the worldly', the Christian has his worldliness. ${ }^{95}$ Finding the life of the Christian to be a certain seizing of the here and now, Paul collapses the distinction between mortal time and eternity: 'The being-present of God has a basic relationship to the transformation of life'. ${ }^{96}$ Equipped with this new, reduced temporality it is but a short step to the reduction of the dual commandment that we are seeking to contextualise here. The Christian does not love her neighbour because that is what people do; rather, she appropriates love of neighbour as her own because she has grasped that love is constituted only in the loving of the neighbour. The life of this Christian is not determined by its worldliness even as it remains entirely this-worldly. Love, absent from worldly relations as such, nonetheless is through its enactment in the world.

\section{Appropriation or use?}

Agamben's brief discussion of Heidegger's The Phenomenology of Religious Life does not hide that Heidegger had already identified the significance of worldliness in Paul's letters_-primoradial Christian life is only the appropriation of worldliness. ${ }^{97}$

The significance of such appropriation, understood now as the seizing of everydayness, for the discussion of authenticity in Heidegger's Being and Time is well known. ${ }^{98}$ Perhaps less well known is the later Heidegger's turn towards the event of appropriation (Ereignis) as something that happens to Dasein, rather than something that Dasein does. ${ }^{99}$ In any case, with this early discussion of Paul's appropriation of his worldly condition, we are at the heart of Heidegger's enduring concerns. It is thus no mere quibble when Agamben finds Paul's hos me to be better

\footnotetext{
94 Ibid., 223.

${ }^{95}$ Heidegger, The Phenomenology of Religious Life, 74.

96 Ibid., 66.

97 Ibid., 34.

${ }^{98}$ Heidegger, Being and Time, 244.

${ }^{99}$ Heidegger, Contributions to Philosophy.
} 
understood as 'use' of worldly vocations than appropriation of them. ${ }^{100}$ But what is at stake in this difference that, at first glance, seems negligible? Agamben's question mark over 'appropriation' (in truth, this is a question mark that the later Heidegger had already placed himself) is twofold. On the one hand, messianic subjectivity is defined by no propriety whatsoever, even that which is only appropriated. Nothing is proper to the messianic subject. ${ }^{101}$ To say that the hos me allows a grasping of worldliness is still to suggest a passage outside of the world. The subject that can seize its worldly condition must be outside of it in some sense. This is not yet full being-in-the-world; otherworldliness remains.

The messianic subject cannot appropriate its worldliness but, for the very same reason, neither can it take hold of itself as a whole. ${ }^{102}$ Being nothing other than its worldliness, not being outside of its worldliness, there is no messianic subject as such. Messianic subjectivity is found only in the revocation (not the appropriation) of its worldly vocations, as the hos me specifies. To paraphrase Nietzsche, there is no messianic doer behind the hos me deed. ${ }^{103}$ In this reading of Paul's messianic vocation we reach, in turn, the heart of Agamben's thought. Agamben's abiding formulation 'form-of-life' is the attempt to think beyond any subject which pre-exists living. In place of this subject, which appears as 'bare life' in western politics, Agamben seeks to articulate that form that is generated only in living and only that life that takes its form. ${ }^{104}$ With form-oflife, so-called vitalist philosophy, philosophy that gives priority to 'life', is rejected just as much as any metaphysical-humanist prioritization of form. The inseparability of a life from its form and a form from its being lived is what is decisive. This is why Paul's "'new creature" is only the capacity to render the old inoperative and use it in a new way.' ${ }^{105}$ The form of life that messianic living renders from-of-life is not replaced but only rendered habitable, as it were. In messianic time, the old form, now deactivated, is really lived in. The messianic vocation coincides completely with the living of a life. ${ }^{106}$

Returning to the Pauline reduction, it is striking how Agamben's form-of-life enables us to link the hos me to Paul's reduced commandment: Love of God is deactivated (that is, rendered

\footnotetext{
100 Agamben, The Time that Remains, 34.

101 Ibid.

102 Ibid.

103 Nietzsche, On the Genealogy of Morality, 26.

104 Agamben, The Use of Bodies, 224.

105 Ibid., 56.

106 Ibid., 227.
} 
inoperative without in any way being replaced) in love of neighbour. Love of God is now inhabited by, is, love of my neighbour.

\section{Conclusion}

The Pauline reduction of Jesus' dual commandment demands to be taken very seriously. As Taubes rightly observed, Paul could not have been unaware of the importance of this twin commandment to the congregations, given how clearly it came to be expressed, later, in the Gospels. The dual commandment must have been at the heart of the teachings of Jesus. Given this, Paul's reduction of the dual commandment to the lesser of the two commands smacks, as Taubes did not shy away from pointing out, of a Pauline polemic against Jesus himself; a polemic motivated, maybe, by something even worse: Paul's ambivalence to God the father of Jesus.

Yet we have seen that this extreme thesis is rather less necessary if Paul's messianism is interrogated closely. In particular, the hos me of 1 Corinthians 7.29-32, which Agamben describes as the fundamental term of Paul's messianism and which Heidegger also focuses on, offers a way through the problem. From the standpoint of the hos me, messianic living is not something that arrives from the outside as a supplement to worldly existence. If this were the case, then worldliness would have to be considered as irredeemably fallen and nothing of it, including love of neighbour, could stand without that supplement. Love of neighbour would indeed need to refer to something higher, to love of God. We would love our neighbour as if not loving him; that is to say, would love God through him.

When we love our neighbour 'as not' loving him, on the other hand, our love refers to nothing higher than our neighbour himself. Both Heidegger and, following him, Agamben, insist that hos me should be translated in this way, namely with 'as not' rather than 'as if not'. The idea here is that Paul sees worldliness not as something to be replaced but rather as something that is revoked in the Messiah. The question of what this re-vocation of every worldly vocation means is treated differently by the early Heidegger in his lectures on Paul and Agamben in The Time That Remains. For Heidegger, revoked worldliness is appropriated authentically when the believer's abandonment is truly faced and there is no displacement into the future, when the Messiah might return. Knowing that Christian existence is not waiting around for another life but only a mode of that self-same living that perdured before the call, the Christian suffers. But this suffering is a mark of having really heard the call. 
For Agamben, revoked worldliness is not an occasion for suffering but for living. Finding its worldly vocations to refer to nothing but themselves, messianic life enjoys an increase in tension by which worldliness can really be lived. Is this difference between a bos me that increases suffering and one that intensifies living only a difference in emotional register? Could it not hint at a more fundamental difference between Heidegger's philosophical obsession with death and Agamben's attempt (after Spinoza) to dwell, rather, on living: 'A free man thinks of nothing less than of death, and his wisdom is a meditation on life, not on death'. ${ }^{107}$

Yet this difference, significant as it is, does not prevent both Heidegger and Agamben being able to locate Paul's reduction of the dual commandment in the wider context summarised by the hos me. The shared emphasis on dwelling in the call, which Heidegger calls enactment and Agamben use, is possible only because worldly vocations remain in place. Convinced that worldliness is the home of messianic-Christian dwelling, Paul reduces love of God to love of neighbour because the neighbour dwells right here in the world next to me.

107 Spinoza, Ethics, 151. 


\section{References}

Agamben, G. The Time That Remains: A Commentary on the Letter to the Romans. Translated by P. Dailey. Stanford: Stanford University Press, 2005.

Agamben, G. The Use of Bodies. Translated by A. Kotsko. Stanford: Stanford University Press, 2016.

Augustine. The City of God Against the Pagans. Translated by H. Bettenson. Harmondsworth: Penguin, 1972.

Barber, D. C. “The Power of Nothingness: Negative Thought in Agamben.” Symposium: Canadian Journal of Continental Philosophy 15, no. 1 (2011): 49-71.

Bielik-Robson, A. “A Broken Constellation: Agamben's Theology between Tragedy and Messianism." Telos 152 (2010): 103-26.

Blanton, W. “Dispossessed Life: An Introduction to Stanislas Breton's Paul.” In A Radical Philosophy of St Paul, by S. Breton, translated by J. N. Ballan. New York: Columbia University Press, 2011.

Bornkamm, G. Paul. New York: Harper and Row, 1971.

Brague, R. The Wisdom of the World: The Human Experience of the Universe in Western Thought. Translated by T. L. Fagen. London: University of Chicago Press, 2003.

Breton, S. The Word and the Cross. Translated by J. Porter. New York: Fordham University Press, 2002.

Breton, S. A Radical Pbilosophy of St Paul. Translated by W. Blanton, New York: Columbia University Press, 2011.

Bultmann, R. Theology of the New Testament. Translated by K. Grobel, Waco: Baylor University Press, 2007.

Cimino, A. "Europe and Paul of Tarsus: Giorgio Agamben on the Overcoming of Europe's Crisis." In Saint Paul and Philosophy: The Consonance of Ancient and Modern Thought, edited by G.J. van der Heiden, G.H. van Kooten and A. Cimino. Berlin: de Gruyter, 2017.

Delahaye, E. “About Chronos and Kairos: On Agamben's interpretation of Pauline temporality through Heidegger." International Journal of Philosophy and Theology 77, no. 3 (2016): 85-101.

Fox, C. A. "Sacrificial Pasts and Messianic Futures: Religion as a political prospect in René Girard and Giorgio Agamben.” Philosophy and Social Criticism 33, no. 5 (2007): 563-95.

Gold, J. “Jacob Taubes: ‘Apocalypse from Below’.”, Telos 134 (2006): 140-56.

Furnish, V. P. Jesus According to Paul. Cambridge: Cambridge University Press, 1993.

Heidegger, M. Being and Time. Translated by J. Stambaugh. Albany: SUNY, 1996. 
Heidegger, M. The Phenomenology of Religious Life. Translated by M. Fitsch and J. A. Gosetti-

Ferencei. Bloomington: Indiana University Press, 2004.

Heidegger, M. Contributions to Philosophy (of the Event). Translated by R. Rojcewicz and D. VallegaNeu. Bloomington: Indiana University Press, 2012.

Horsley, R. Paul and Empire: Religion and Power in Roman Imperial Society, Harrisburg, PA: Trinity Press International, 1997.

Johnson, D. E. “As If the Time Were Now: Deconstructing Agamben." South Atlantic Quarterly 106, no. 2 (2007): 265-90.

Løland, O. J. Pauline Ugliness: Jacob Taubes and the Turn to Paul. New York: Fordham University Press, 2020.

Lynch, T. Apocalyptic Political Theology. London: Bloomsbury, 2019.

Nietzsche, F. On the Genealogy of Morality, Translated by C. Diethe. Cambridge: Cambridge University Press, 1994.

Poorthuis, M. "The A-Cosmic Doctrine of Marcion and Paul's Apocalypticism: Theo-Political Implications.” Political Theology 17, no. 3 (2016): 289-296.

Spinoza. Ethics. Translated by E. Curley. London: Penguin, 1996.

Spinoza. Theological-Political Treatise. Translated by J. Israel. Cambridge: Cambridge University Press, 2007.

Styfhals, W. "Evil in History: Karl Löwith and Jacob Taubes on Modern Eschatology." Journal of the History of Ideas 76, no. 2 (2015): 191-213.

Styfhals, W. No Spiritual Investment in the World: Gnosticism and Postwar German Philosophy. Ithaca: Cornell University Press, 2019.

Swazo, N. K. 'Heidegger's Destruktion of Theology: 'Primordial Faith' and 'Recognition' of the Messiah.” Modern Theology 35, no. 1 (2019): 140-162.

Taubes, J. “Against the Stream, by Karl Barth.” Commentary September 1954.

Taubes, J. The Political Theology of Paul. Translated by D. Hollander. Stanford: Stanford University Press, 2004.

Taubes, J. Occidental Eschatology. Translated by D. Ratmoko. Stanford, CA: Stanford University Press, 2009.

Vedder, B. "Heidegger's Explication of Religious Phenomena in the Letters of Saint Paul." Bijdragen 70, no. 2 (2009): 152-167.

Weigel, S. "In Paul's Mask: Jacob Taubes Reads Walter Benjamin.” In Genealogies of the Secular: The Making of Modern German Thought, edited by W. Styfhals and S. Symons. New York: SUNY Press, 2019. 